\title{
The Polymorphic Acetylation of Sulphapyridine in Man
}

\author{
HASSE SCHRÖDER and DAVID A. PRICE EVANS
}

\section{Department of Zoophysiology, University of Uppsala and Pharmacia AB, Uppsala, Sweden, and Department of Medicine, University of Liverpool, UK}

Since 1941 salicyl-azo-sulphapyridine (sulphasalazaline) has been used in the treatment of ulcerative colitis (Svartz, 1942). The drug undergoes extensive cleavage of the azo linkage in vivo (Svartz, Kallner, and Helander, 1945; Böttiger and Möllerberg, 1959; Schröder and Campbell, 1971) and the sulphapyridine thus formed is subject to $\mathrm{N}^{4}$-acetylation and simultaneous ring hydroxylation. The hydroxylated metabolite is recovered in the urine entirely as its O-glucuronide. The absence of free hydroxylated sulphapyridine in urine indicates that the hydroxylation is the rate-determining step in the formation of the glucuronide (Schröder and Campbell, 1971). The disposition of sulphapyridine in man is shown in Fig. 1.

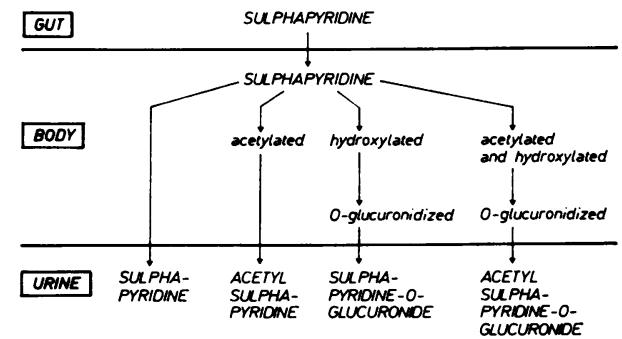

Fig. 1. Scheme of disposition of sulphapyridine. The disposition of sulphadimidine is simpler since it is not hydroxylated, and appears in the urine as the unchanged drug and as acetyl sulphadimidine only.

It has been shown that the acetylation of isoniazid, sulphadimidine, hydrallazine (Evans and White, 1964), and dapsone (Gelber et al, 1971) are subject to a genetic polymorphism.

The purposes of the present study were: (1) to establish whether sulphapyridine is subject to polymorphic acetylation, and (2) to see if there is a similar polymorphic hydroxylation of the drug.

Received 11 October 1971.

\section{Materials and Methods}

Subjects without a history of asthma, hay fever, $\stackrel{\circ}{\sim}$ eczema, adverse reactions to any drug, or gastrointes- $\underset{\infty}{\infty}$ tinal disorders participated in the study. The subjects 0 were hospital staff and medical students and, with one exception, were British and white. Age, body weight, $\overrightarrow{\vec{c}}$ and height of the subjects are given in Table I (lines 10, 11 , and 12).

Sulphadimidine (quality B USP 17, Chemapol) and $\vec{\varphi}$ sulphapyridine (quality B USP 17, May and Baker) were used as powder. The dose of both drugs was $10.0 \mathrm{mg} /$ $\mathrm{kg}$ body weight and it was ingested as a powder from aluminium foil.

Procedure. The subjects were phenotyped as slow or rapid acetylators of sulphadimidine according to the $\varrho$ simplified method described by Evans (1969). One $\overrightarrow{\vec{O}}$ week later the procedure was repeated with sulpha- 3 pyridine. The procedure was then slightly modified so that urine was collected between 7th and 8th hour after drug ingestion and the blood sample was taken after 8 hours.

Chemical Procedure. Concentrations of nonacetylated and total sulphadimidine and sulphapyridine in serum and urine were determined by a slight modification of the Bratton and Marshall procedure (1939). A 을 1-ml sample of serum was added to $2 \mathrm{ml}$ of $15 \%$ trichloroacetic acid. After shaking and centrifugation, $1 \mathrm{ml}$ of the supernatant was added to each of 2 test tubes containing $2 \mathrm{ml}$ of $0.06 \%$ sodium nitrite and $1 \mathrm{ml}$ of $2 \mathrm{M}$ \% hydrochloric acid, respectively. The latter test tube was N placed in a boiling water bath for 20 minutes and then $\mathrm{N}$ $1 \mathrm{ml}$ of $0.06 \%$ sodium nitrite was added. After $5 \mathrm{\omega}$ minutes, $1 \mathrm{ml}$ of $0.8 \%$ ammonium sulphamate was added to both test tubes followed 2 minutes later by $1 \mathrm{ml}$ of $0.8 \% \mathrm{~N}$-1-naphthylethylenediamine dihydrochloride. The absorbance was measured at $547 \mathrm{~nm}$ in a spectrophotometer. For determination in urine, $50 \mathrm{ml}$ of urine was added to each of 2 test tubes containing $1 \mathrm{ml}$ of $1 \mathrm{M}$ hydrochloric acid. One of the test tubes was placed in a boiling water bath for 20 minutes. Both specimens were then handled as for non-acetylated sulphonamide in serum. Concentrations of hydroxylated 
TABLE I

COMPARISON OF MEAN VALUES FOR SLOW AND RAPID ACETYLATORS

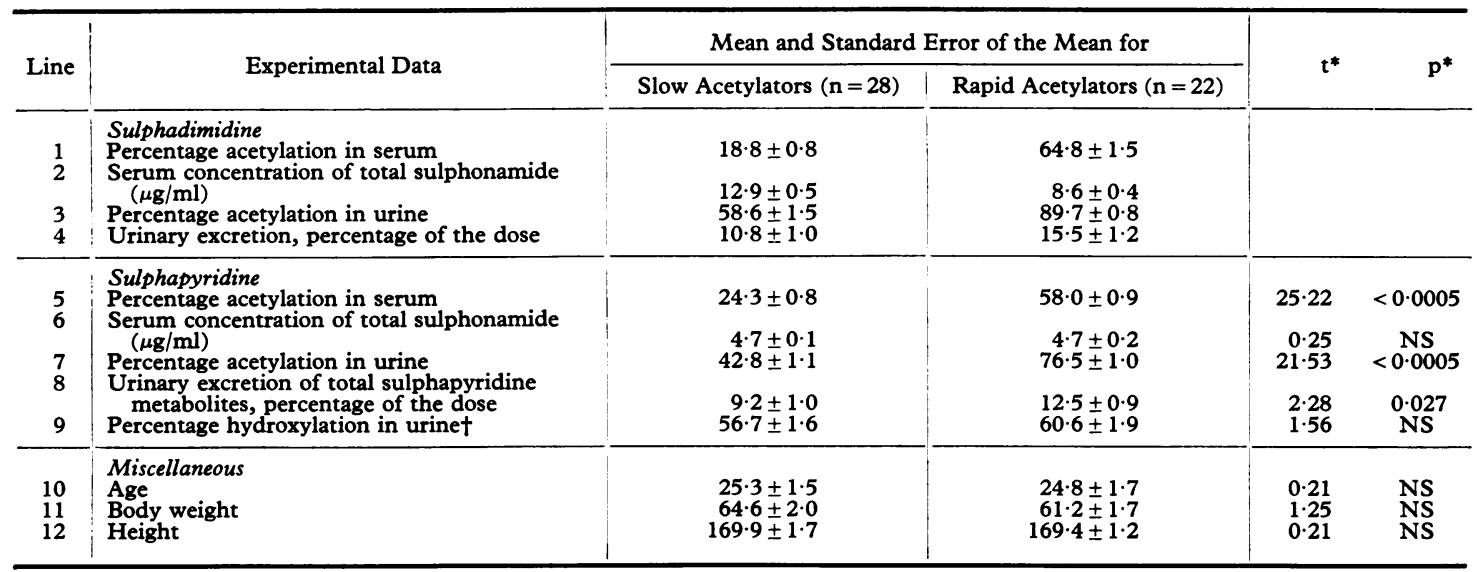

* Differences between slow and rapid acetylators were tested by Student's test.

t Two extremely poor hydroxylators (one of each acetylator phenotype) were omitted from the calculations. When they were included the $t$ value was found to be $1 \cdot 11$.

sulphapyridine were determined in the urine specimens according to the procedure given by Hansson and Sandberg (1971). All determinations were performed in duplicate together with suitable blanks.

\section{Results}

From Figs. 2 and 3 and from Table I (lines 1, 3, 5, and 7) sulphapyridine seems to be equally good as a discriminator of the acetylator phenotypes as sulphadimidine. All subjects phenotyped as slow

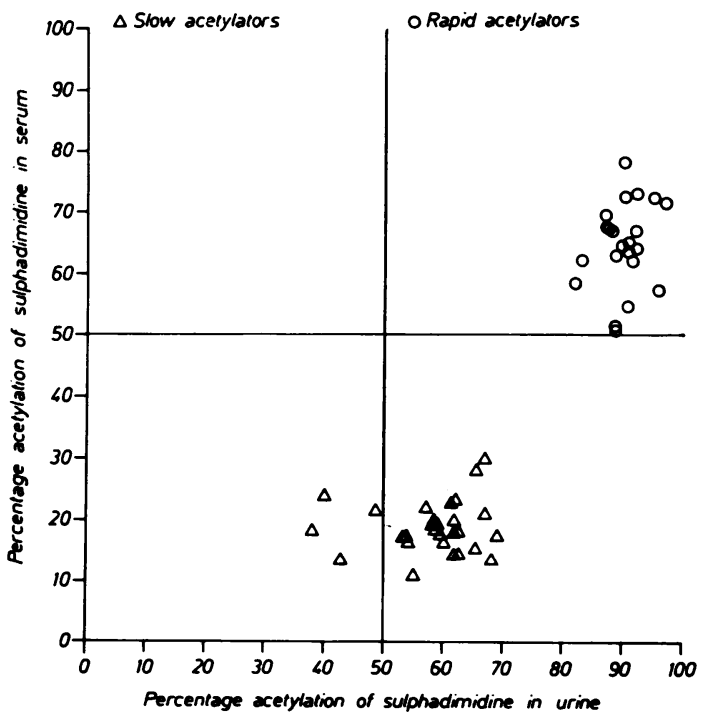

FIG. 2. Results on phenotyping 50 subjects as slow or rapid acetylators with sulphadimidine. acetylators of sulphadimidine, were found to be slow acetylators of sulphapyridine. Similarly the same individuals were rapid acetylators of both compounds. The incidence of slow acetylators was $28 / 50=56 \%$. The serum concentrations of total sulphadimidine were significantly higher for the slow acetylators (Table I, line 2). However, both acetylator phenotypes had similar serum concentrations of total sulphapyridine (Table I, line 6). The slow acetylators excreted a significantly smaller

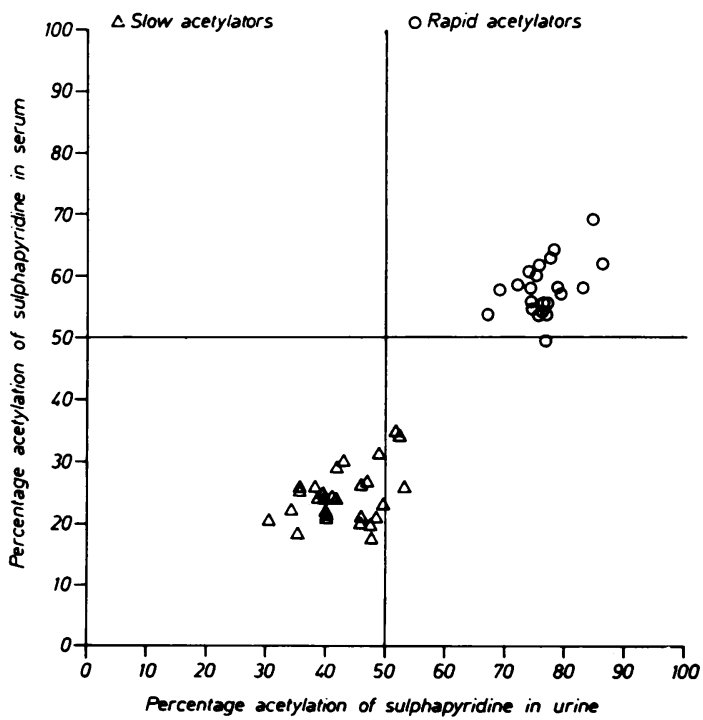

Fig. 3. Results of tests with sulphapyridine on $\mathbf{5 0}$ subjects previously phenotyped with sulphadimidine. 
portion of the dose of both drugs than the rapid acetylators in the 1-hour urine collection (Table I, lines 4 and 8). The regressions of percentage acetylation of sulphadimidine and sulphapyridine in serum and urine $(y)$ upon age, body weight, and height $(x)$ were calculated, and found not to be significant. There was no significant association between sex and acetylator phenotype.

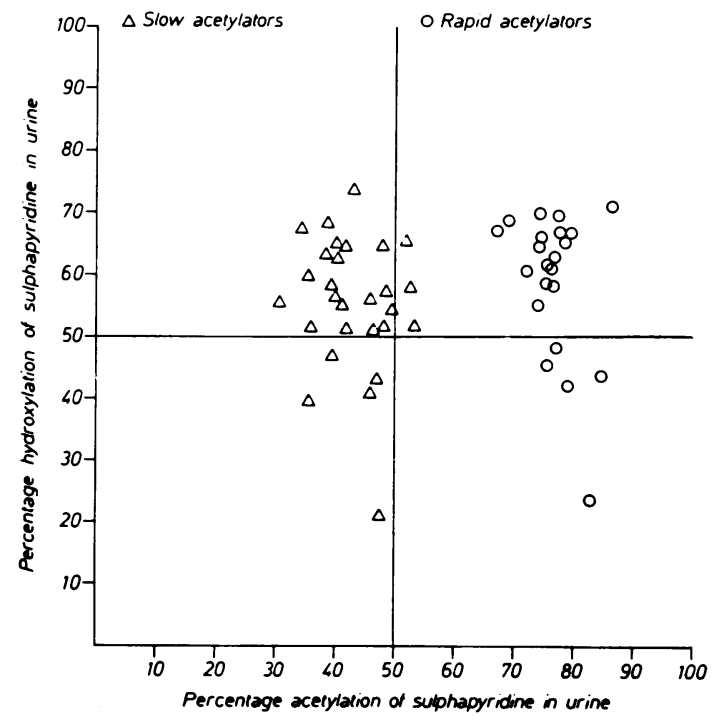

Fig. 4. Relationship between percentage of acetylated sulphapyridine in urine $(x)$ and percentage of hydroxylated sulphapyridine in the urine $(y)$ from 50 subjects.

In Fig. 4, the percentage of acetylated sulphapyridine $(x)$ is plotted against the percentage of hydroxylated sulphapyridine in urine $(y)$. The distribution histogram for the hydroxylation of sulphapyridine in urine was skew. Two subjects, one of each acetylator phenotype, were very poor hydroxylators of sulphapyridine.

There was a significant difference in the percentage of hydroxylated sulphapyridine in urine between rapid and slow acetylators whether or not the two poor hydroxylators were included (Table I, line 9).

In order to elucidate whether the rate of hydroxylation has any influence on the serum concentration of total sulphapyridine, the regression of serum concentrations of total sulphapyridine $(y)$ on percentage of sulphapyridine in urine in hydroxylated form $(x)$ was calculated. No significant correlation was found even when the 2 poor hydroxylators were omitted.

\section{Discussion}

The results show that acetylation of sulphapyridine is subject to the same genetic polymorphism as is sulphadimidine, isoniazid, hydrallazine, and dapsone. The frequency of slow acetylators was in the same range as reported by Evans (1969).

The acetylator phenotype strongly influences the degree of acetylation in serum and urine of both drugs tested here and the 1-hour urinary recoveries of them. The acetylator phenotype also affects the serum concentration of total sulphadimidine (this study), the plasma concentration of isoniazid (Evans, Manley, and McKusick, 1960), and the plasma ratio of acetylated to parent dapsone (Gelber et al, 1971). However, in this study the mean serum concentration of total sulphapyridine is similar for both phenotypes (Table I, line 6). One reason for this may be that sulphapyridine and acetylsulphapyridine also undergo substantial ring hydroxylation. The hydroxylated metabolites appear in the blood and urine as O-glucuronides. Approximate renal clearance values are as follows, sulphapyridine, $10 \mathrm{ml} / \mathrm{min}$; acetylsulphapyridine, $30 \mathrm{ml} / \mathrm{min}$; sulphapyridine-O-glucuronide, $200 \mathrm{ml} /$ $\mathrm{min}$; and acetylsulphapyridine-O-glucuronide, 64 $\mathrm{ml} / \mathrm{min}$ (Schröder and Campbell, 1971). The present study shows that both acetylator phenotypes hydroxylate (glucuronidize) sulphapyridine to the same extent (Fig. 4 and Table I, line 9). The rapid acetylators transform the major portion of the poorly excreted sulphapyridine into equal amounts of each of the 2 acetylated metabolites with 3 and 6 times higher renal clearance values, respectively. The slow acetylators, however, excrete a greater portion as the 2 unacetylated metabolites of sulphapyridine (Table I, line 7). About half of this is sulphapyridine and the other half is sulphapyridine-Oglucuronide, the latter metabolite being excreted 20 times more rapidly than the parent drug (Table II). Hence the higher serum concentration of sulphapyridine for slow acetylators is effectively lowered by formation of the O-glucuronide. The effect of the

TABLE II

PERCENTAGE RECOVERY IN THE URINE OF A DOSE OF SULPHAPYRIDINE AS PARENT COMPOUND AND METABOLITES

\begin{tabular}{l|c|c|c|c}
\hline \multicolumn{1}{c}{ Compound } & $\begin{array}{c}\text { Renal } \\
\text { Clearance } \\
(\mathrm{ml} / \mathrm{min})\end{array}$ & \begin{tabular}{c} 
Mean Percentage Recovery \\
\cline { 4 - 5 }
\end{tabular} & $\begin{array}{c}\text { Slow } \\
\text { Acetylator }\end{array}$ & $\begin{array}{c}\text { Rapid } \\
\text { Acetylator }\end{array}$ \\
\hline $\begin{array}{l}\text { Sulphapyridine } \\
\text { Sulphapyridine-O- }\end{array}$ & 10 & 25 & 9 \\
$\begin{array}{l}\text { glucuronide } \\
\text { Acetyl sulphapyridine }\end{array}$ & 200 & 32 & 14 \\
Acetyl sulphapyridine- & 30 & 18 & 30 \\
O-glucuronide & 64 & 25 & 47 \\
\hline
\end{tabular}


acetylator phenotype on the serum concentration of total sulphapyridine thus seems to be compensated by the effect of the hydroxylating mechanism.

The apparent bimodality in the distribution of the degree of hydroxylation of sulphapyridine in urine may be explained by (1) an extreme skewness of the character in the population or (2) the existence of a polymorphism in hydroxylation of sulphapyridine. Which of these alternatives is most applicable to sulphapyridine cannot be established without surveying a considerably larger sample, because of the low frequency of the poor hydroxylators.

\section{Summary}

It is shown that sulphapyridine is an equally good discriminator of slow and rapid acetylator phenotypes as sulphadimidine. The acetylator phenotype strongly influences the serum concentration of sulphadimidine but not that of sulphapyridine. It is suggested that the hydroxylation and subsequent conjugation of sulphapyridine to glucuronic acid compensates the effect of the acetylator phenotype upon the serum concentration of sulphapyridine. The distribution of the percentages of hydroxylated sulphapyridine in urine is skewed and 2 subjects out of 50 have very low values. It has not been established whether there is simply an extreme skewness in the population frequency distribution or whether there exists a polymorphism in the hydroxylation of sulphapyridine.

The authors wish to thank Miss M. F. Bullen for assistance in performing the phenotyping tests, and $\mathrm{Dr} \mathrm{J}$. Ekstedt (Pharmacia A.B.) for financial support.:

\section{REFERENCES}

Bratton, A. C. and Marshall, E. K. (1939). A new coupling component for sulfanilamide determination. Fournal of Biological Chemistry, 128, 537-550.

Böttiger, L. E. and Möllerberg, H. (1959). Metabolic studies on azulfidine, azudimidine and one analogue. Acta Medica Scandinavica, 165, 241-244.

Evans, D. A. P. (1969). An improved and simplified method of detecting the acetylator phenotype. Fournal of Medical Genetics, 6, 405-407.

Evans, D. A. P., Manley, K. A., and McKusick, V. A. (1960). Genetic control of isoniazid metabolism in man. British Medical Fournal, 2, 485-491.

Evans, D. A. P. and White, T. A. (1964). Human acetylation polymorphism. Fournal of Laboratory and Clinical Medicine, 63, 394403.

Gelber, R., Peters, J. H., Gordon, G. R., Glazko, A. J., and Levy, L. (1971). The polymorphic acetylation of dapsone in man. Clinical Pharmacology and Therapeutics, 12, 225-238.

Hansson, K.-A. and Sandberg, M. (1971). Determination of sulfapyridine and its metabolites in biologic materials after administration of salicylazosulfapyridine. (Submitted for publication.)

Schröder, H. and Campbell, D. (1971). Absorption, metabolism and excretion of salicyl-azo-sulfapyridine in man. Clinical Pharmacology and Therapeutics. (In press.)

Svartz, N. (1942). Salazopyrin, a new sulfanilamide preparation. Acta Medica Scandinavica, 110, 577-598.

Svartz, N., Kallner, S., and Helander, S. (1945). Sönderdelas salazopyrin snabbt i organismen ? Nordisk Medicin, 25, 211-212. 